\section{Har historikerne svigtet samfundet?}

Af Thorkild Kjærgaard

Historien rummer mange eksempler på, at fundamentale ændringer af den menneskelige civilisation kan indtræffe meget hurtigt. Østblokkens uventede sammenbrud for få år siden er et eksempel. Man kunne også nævne slaveriet. Det var vidt udbredt i 1800 -tallet. Alligevel blev det i de fleste lande afskaffet i løbet af 20-30 år. Velfærdsstater blev i mellemkrigstiden opbygget overalt i Vesteuropa på ganske få år, delvis som en reaktion på den russiske revolution, der også er et eksempel på, hvor hurtigt forandringer kan indtræffe, når først begivenhederne kommer i skred.

Bevidstheden om, at altomfattende kvalitative forandringer kan ske hurtigt, er måske den vigtigste indsigt, historien overhovedet kan give. I en tid som vores, hvor én milliard mennesker sulter - flere end den samlede verdensbefolkning for 200 år siden - og hvor pengemagten har bredt sig i en hidtil uset grad, er det trøsterigt at vide, at fundamentale forandringer har fundet sted og derfor med overvejende sandsynlighed vil finde sted igen. Bevidstheden om forandringens mulighed er den revolutionære, ultimativt-radikale indsigt, som det er historikernes opgave at vedligeholde og viderebringe. Alle regimer har til alle tider prøvet at overbevise verden om, at de er den eneste mulighed. Det gælder også i dag. Nyliberalisternes højlydte budskab er, at der ikke eksisterer noget alternativ til den globale kapitalisme, og at menneskeheden har nået sin kulmination efter kommunismens sammenbrud og de klassiske, venstreorienterede socialdemokratiers angivelige fallit. Det er også budskabet bag den amerikanske polito$\log$ og historiker Fukujamas tiljublede bog The End of History, en moderne pendant til Hegels Philosophie der Geschichte.

Trods den megen snak om historiens afslutning er der ingen tvivl om, at radikale forandringer er mulige. De er mere end det, de er uundgåelige, så vist som alle væsentlige miljømæssige, sociale og demografiske indikatorer peger i den gale retning. Selv om spillerummet ikke er stort mellem de anonyme økonomiske kræfter og den økologiske nødvendighed, er det relevant at spørge, hvor vi skal søge kilderne til innovativ social og idémæssig tænkning. Både litteratur og kunst kan i vid udstrækning opfattes som afsøgninger af alternative muligheder, af andre måder at leve på og er som sådan dele af et stort utopisk- revolutionært projekt. Men der er også de uendeligt mange sociale virkeligheder, som har eksisteret før os, det vi kalder historien. Historie er et repertoire af muligheder, som det er historikernes opgave at fastholde og viderebringe ved at gå ind i en kritisk dialog med fortiden. Man skal ikke fortabe sig i fortiden, så bliver man nostalgisk og fremmed for sin egen tid 
som de folk, der om sommeren sidder og nørkler i jernalderlandsbyen i Lejre eller som dem, der murer sig inde $\mathrm{i}$ mytologier om besættelsen. Man skal heller ikke stirre sig blind på det almenmenneskelige, det umiddelbart genkendelige, som får en til at overse, hvor forskelligt det almenmenneskelige trods alt ytrer sig til forskellige tider. Det er netop i mødet mellem tiderne, mødet mellem før og nu, mellem fortid og nutid, det kan slå gnister, og her har professionelle historikere en særlig rolle. Historie skal - med et udtryk lånt fra Arne Næss - være relationistisk. Det er min opfattelse, at det for øjeblikket kniber på dette punkt, at historikerne har svigtet deres rolle både i forhold til sig selv og i forhold til samfundet.

Måske er det som så meget andet computerens skyld. Da pc-erne dukkede op i midten af $1980^{\prime}$ 'erne, steg antallet af indsendte artikler til American Historical Review med 40-50\% i løbet af et år eller to. På forlagene kunne man konstatere, at manuskripterne blev flere og - især - større. Computerne har afsat en form for bulimi eller videnskabelig elefantitis i historikerverdenen. Når der bevilges penge til et RUC-baseret projekt om historieformidling, får vi ikke bare én bog om historieformidling, vi får et bogværk på 11 bind, som skrives $\mathrm{i}$ et rasende tempo. Vi făr ikke ét stramt, velredigeret bind om Danmark-Norges historie, når tvillingrigernes historie sættes på programmet, vi får fire store uredigerede bind, uden hovedredaktør, hvor hver forfatter breder sig som det passer ham. Monografier er sjældent under 500 sider. En biografi om lægen
N. K. Jerne kan ikke afvikles på mindre end 700 sider, en bog om forureningsbekæmpelsen i Danmark mellem 1850 og 1974 breder sig over 650 sider, arbejdskampenes historie mellem 1870 og 1939 fylder 450 tættrykte sider, og skal der gøres op med Edvard Holms teser om stavnsbåndet, kræver det 450 endnu mere tættrykte sider. En redegørelse for bøndernes forhold i Malt herred i 1600-tallet: 800 sider, Polyteknisk Læreanstalts grundlæggelse: 500 sider, stadsmusikantvæsenet i Danmark: 800 sider. Man kan godt få fornemmelsen af at være ved at blive kørt over, når man ser disse mammutværker brede sig hos boghandleren og på bogreolen. Alle disse kilo, alle disse svenske og finske skove, det er næsten ikke til at holde ud, når man tænker på, hvor lidt substans, der er inden i papiret og hvor meget sludder og vrøvl man skal igennem, før man finder det guldkorn, der måske gør læsningen umagen værd. Det frygtelige er nemlig, at nok gør computeren det muligt at skrive hurtigere, men åbenbart ikke at tænke hurtigere. Måske er den simple kendsgerning, at der i Danmark er for lidt talent til at præstere så mange tusind sider, som der årligt skrives om historie. De historiske bogværker myldrer frem, jo større, jo bedre. DanmarksNorges historie, toldhistorien, P\&Ts historie, den danske søfarts historie, det danske landbrugs historie og dansk identitetshistorie. Og det bliver bare ved og ved. En stor dansk forvaltninghistorie skulle være lige på trapperne, og der er, oplyses det, bevilget 10-20 millioner af Carlsbergfondet til et værk i mange bind om dansk udenrigspolitiks historie. 
Fælles for disse bogværker er, at de altid kommer til tiden. Forrige tiders dramaer om bøger, der lod vente på sig år efter år, mens forfatterne kæmpede med stoffet, hvis ikke de ligefrem slog sig ihjel på det som Erik Arup og C. O. Bøggild-Andersen, er helt forsvundne. Moderne historikere er som det højproduktive erhvervsliv driftssikre og toptunede, altid leveringsdygtige just in time, de skriver det dagligt normerede antal sider og synes ikke at have voldsomme erkendelsesmæssige problemer, hvad der ved eftersyn måske er en del af problemet.

Fælles for disse bindstærke produktioner er endvidere, at de så godt som altid er skrevet af forfatterteams med vidt forskellige opfattelser, og at de er svagt eller slet ikke redigerede. En fælles linie mener man tilsyneladende ikke er nødvendig. Resultatet er, at bøgerne går døde, bliver reaktionsløse, virker uenergiske og ikke-relationistiske. De er i dybeste forstand uden samfundsrelevans, uden perspektiv, uden antydning af svar på noget som helst.

Danmark-Norges historie, der befatter sig med et spændende og i højeste grad aktuelt emne, nemlig flerkulturelle samfunds eksistensbetingelser her i Norden, ville være et glimrende udgangspunkt for relationistisk historieskrivning. Vi er i disse år på vej mod et flerkulturelt samfund - kan det gå? hvordan gik det? - spørgsmålene myldrer frem. Noget lignende gælder for et værk som det danske landbrugs historie. Det er, i betragtning af det nuværende landbrugs dybe krise, svært at forestille sig et emne mere velegnet for rela- tionistisk historieskrivning. Men det afspejles ikke i Det danske landbrugs historie, hvor det ene bind følger det andet, alt imens de modsiger hinanden og sig selv i én uendelighed og i alle mulige retninger, uden at der bliver gjort noget som helst forsøg på at sætte tingene ind i en større sammenhæng.

Jeg tror, denne udvikling er skadelig. Ikke lige det enkelte værk i sig selv, men summen af de mange værker kan skade, blandt andet på den måde, at markedet drænes for forskningsmidler. I gamle dage undertrykte man den frie forskning med censur. Det gør man ikke mere. Denne helt forældede måde at drive forskningspolitik på overlader man gerne til nazister og til det hedengangne Sovjetunionen og Østeuropa. I stedet blokerer man faget ved at søsætte et uendeligt antal historiske storværker, som man sætter effektive, pålidelige og businessagtige historikere til at skrive efter recepten: og så - og så - og så - og så. Det er moderne, resultatorienteret forskningspolitik.

Der er - forekommer det mig i de senere år blevet sat en ny standard for professionel historisk forskning. Det vigtigste er, at man bliver færdig med sit projekt til tiden, og at man ikke fornærmer arbejdsgiveren, der meget ofte er en fond eller en anden privat arbejdsgiver. Er disse to betingelser opfyldt, kan man håbe på nye opgaver og nye bevillinger. Det har også - følgerigtigt - sat nye idealer for forskeruddannelsen. En ung forskerspire skal tilpasse sig et ph.d.program, ensomme jægere på jagt efter erkendelse i fremmede egne, som det tidligere forskeruddannelsessystem til- 
lod, nærmest opmuntrede til, accepteres ikke længere. Man skal holde sig til flokken og tættest muligt på førerhunden, man skal kunne „arbejde i team“, enkeltpræstationer anses i bund og grund for forældede. Desuden skal man publicere, jo før jo bedre. Deri ligger også en kraftig opfordring til ikke at vige ud til siden. Århus-forskeren Jens Christian Skou, der 1997 modtog Nobelprisen i medicin, forskede i otte år uden at publicere noget. Han ville, som han selv gentagne gange både har sagt og skrevet, ikke have haft en chance i dagens medicinske forskningsmiljø. Han ville være blevet squeezet ud længe før han nåede frem til de epokegørende iagttagelser, som indbragte ham Nobelprisen. Tilsvarende tror jeg, at bestemte talenttyper inden for historie - og måske ikke mindst dem, der har evne for relationistisk historieskrivning - ikke længere kan overleve, simpelthen fordi erkendelsesprocessen er langsommere og mere kompleks, hvis man skal finde sig et nyt ståsted, og ikke blot overtager lærernes og professorernes, sådan som man gør det i et effektivt sammenskruet ph.d.- program. Det vil normalt ikke være kapaciteter i Nobelpris-klassen, som skubbes ud, men mindre kan gøre det. Det afgørende og det farlige er, at det er nye forskertyper, som bliver fremmet, de som går lige frem efter næsen og ikke stiller for mange spørgsmål. Man opnår hermed en endimensionalisering og specialisering til skade for historieforskningen, der står i fare for at miste overblikket, miste kontakten med de store, flerdimensionale sammenhænge, som kun kan vedligeholdes ved stadig efterprøvning af den erkendelsesmæssige kontekst.

Den udvikling, som jeg her har forsøgt at skitsere, indgår i en større sammenhæng. Der har i de senere år været en lang diskussion om pressens og mediernes forandrede rolle. En af deltagerne i denne debat er den svenske debattør og forfatter Pia Bótius. Hun har flere gange, blandt andet i bogen De har vendt sig imod os hævdet, at pressen og medierne ikke længere er folkets eller samfundets talerør, men i stigende grad systematisk fortier eller fordrejer socialt relevante problemstillinger. Det er ikke nyt, men pengemagtens aggressive indtrængen i massemedierne, de elektroniske såvel som de klassiske papirbårne, har mangedoblet problemet. Journalister er ikke længere læsernes tjenere, de er ejernes og annoncørernes, det er det, de får deres gode løn for. Bótius nævner som eksempel Clinton-Lewinsky-sagen, der har fået en opmærksomhed, den ikke tidligere ville have opnået. Hun mener, at den skjulte dagsorden bag de smålige og pinligt moraliserende angreb på præsident Clinton er, at politik og den politiske klasse som sådan skal mistænkeliggøres. Det skal politik, fordi politik i et kapitalistisk samfund er folkets eneste værn imod pengemagten, og dermed mod dem, som sidder på medierne. På tilsvarende måde bliver miljøspørgsmål og andre forhold, som på afgørende måde påvirker folkets liv og levevilkår, men som jævnligt kommer på tværs af pengemagtens interesser, systematisk underbelyst og underbetonet. En dilettant som Bjørn Lomborg, der morer sig med at påstå, at hele 
miljøspørgsmålet er en storm i et glas vand, bliver øjeblikkelig pressens yndling og hæves til skyerne af stort set samtlige danske aviser og tv-stationer med Politiken og Berlingske Tidende i spidsen. Debatten om alternative samfundssystemer forties eller latterliggøres, social lighed er dybt godnat, om socialisme kan intet godt siges, folk der er imod EU behandles som idioter. Hele pressen og alle tv-kanaler er for EU, halvdelen af folket er imod, og så videre og så videre.

Det er ikke kun medierne, der har vendt sig imod 'os', altså imod folket. Det gælder også videnskaben. Lægevidenskab tænker ikke et sekund på det, man kunne kalde folkets generelle interesse, den har blikket stift rettet mod medicinalfirmaer, tyggegummifabrikanter og andre forskningssponsorer. Der er ustyrlige pengesummer gemt i allergi- og kræftforskning, der bruges ikke mange penge på overvejelser om de eventuelle alternative samfundssystemer, som kunne reducere forekomsten af kræft og dermed overflødiggøre en del af medicinalindustrien. Landbrugsforskningen arbejder tæt sammen med det agro-industrielle kompleks. I det verdensbillede, disse interesser repræsenterer, er der ikke plads til småbønder og økologisk bæredygtige produktionssystemer.

Og hvad gør historikerne? Ja, de ser vel også først og fremmest på, hvad arbejdsgiverne - forskningsrådene, fondene og andre udefra kommende partnere - kræver. Der er næsten ingen smuthuller mere, heller ikke på universiteterne, der i stigende grad har ladet private penge trænge ind og dermed få direkte indflydelse. Der findes allerede nu professorater i økonomi, betalt af Den danske bank, og det er sikkert kun et spørgsmål om tid, før A. P. Møllerfonden opretter et professorat i økonomisk historie, og behørigt lader sig hylde herfor af den samlede presse. Det hedder sig naturligvis, at der ikke på denne måde lægges hindringer for den fri forskning, modtageren af pengene er fuldstændig fri, ligesom Politiforbundet for et par år siden bedyrede, at det ikke havde lagt nogen form for begrænsninger på den forsker, det havde hyret til at udforske politiets rolle under besættelsen. Det gjorde Forbundet måske heller ikke, men når man læser den pågældende afhandling, skulle man i hvert fald tro, det var sket. På samme måde bedyrer landbruget, at det ikke lægger nogen form for begrænsninger på forskningsfriheden, når det - som det skete i 1980'erne - finansierer en ny landbrugshistorie. Men dét er bevisligt forkert, der blev øvet pres, og redaktionen lod sig presse, blandt andet til at vælge en ny forfatter til afsnittet om 1700-tallet.

Historieforskningens bånd til veldefinerede sociale og økonomiske interesser er blevet mere markante siden slutningen af 1970'erne. Den åbne såvel som den skjulte pression fra opdragsgivere og finansieringskilder har påvirket historieforskningen kendeligt og truer med at skære dens livsnerve over. Det ville være en ulykke ikke bare for faget, men også - tror jeg da - for samfundet som helhed. Det ville betyde, at et af de få tilbageværende åndehuller for fri, 
flerdimensionel tænkning og for erindring om forandringens mulighed og uundgåelighed lukkes. Historie bør ikke kun have en bytteværdi i kampen om stillinger, bevillinger og prestige i fagfællers øjne, den bør også have samfundsmæssig brugsværdi og relevans, den bør på en eller anden måde indgå i den nutidige kamp om vores fælles fremtid. Ellers svigter historikerne samfundet og reducerer sig selv til en af det komplekse postmoderne samfunds utallige selvrefererende grupper. 